\title{
Protective Effect of Celastrus paniculatus Seed Extract against Lead Acetate Induced Nephrotoxicity in Wistar Rats
}

\author{
Karunakaran Balaji1, J Vijayakumar ${ }^{1, *}$, Sivanesan Senthilkumar², Rajagopalan Vijayaraghavan², \\ Viswanathan Naveenkumar ${ }^{2}$ \\ ${ }^{1}$ Department of Anatomy, Saveetha Medical College and Hospital, Saveetha Institute of Medical and Technical Sciences \\ (Deemed to be University), Chennai, Tamil Nadu, INDIA. \\ 'Department of Research and Development, Saveetha Institute of Medical and Technical Sciences (Deemed to be University), \\ Chennai, Tamil Nadu, INDIA.
}

\begin{abstract}
Objectives: The plant Celastrus paniculatus is used in the traditional medical practices of India to treat a plethora of diseases. Earlier research on the plant revealed several biological properties and interesting bioactive compounds with significant medicinal uses. Materials and Methods: In this study, the ethanolic extract of the seeds of the plant (EECP) has been investigated against lead acetate (LA) induced nephrotoxicity in Wistar rats. Thirty rats were divided into five groups $(n=6)$ wherein group 1 that contained normal animals served as control while group 2 received LA $(30 \mathrm{mg} / \mathrm{kgb} . \mathrm{w} / \mathrm{day}$, p.o.). Animals in groups $3-5$ received respectively the standard drug $\mathrm{N}$-acetylcysteine (NAC, $200 \mathrm{mg} / \mathrm{kg}$ b.w/day, p.o.) and EECP in two doses $(400$ and $800 \mathrm{mg} / \mathrm{kgb} . \mathrm{w} /$ day, p.o.) together with LA $(30 \mathrm{mg} / \mathrm{kg}$ b.w/day, p.o.) for 28 consecutive days. On day 29, all the animals were sacrificed and the blood and kidney were collected for analysis. Results and Conclusion: LA significantly decreased the level of catalase (CAT), glutathione peroxidase $(\mathrm{GPx})$, superoxide dismutase (SOD), reduced glutathione (GR), glutathione S-transferase (GST) and glutathione (GSH) and increased the level of hydrogen peroxide $\left(\mathrm{H}_{2} \mathrm{O}_{2}\right)$, hydroxyl radicals $\left(\mathrm{OH}^{-}\right)$and lipid peroxidation (LPO) as compared to those in control rats. Administration of EECP especially $800 \mathrm{mg} / \mathrm{kg}$ b.w. significantly downregulated the serum urea, creatinine and KIM 1 levels and also the level of oxidative stress markers when compared to the LA group. Histological and immunohistochemistry (KIM 1) study showed a significant change in the cytoarchitecture of the renal tissue thereby revealing the pro-active role of $C$. paniculatus seeds in nephrotoxicity.
\end{abstract}

Key words: Celastrus paniculatus seeds, Free radical scavenging activity, KIM 1, Lead Acetate, Nephro-toxicity, Wistar rats.

\section{INTRODUCTION}

Celastrus paniculatus Willd.(Family: Celastraceae) known as Maalakaangni or Vaaluluvai in Tamil and Jyotishmati in Sanskrit is used in Ayurveda and Siddha systems of medicine to treat neurological disorders. Various researches carried out on this plant reported analgesic, antidepressant, anti-inflammatory, antioxidant, neuroprotective and nootropic effects. ${ }^{1-3}$ As the seeds were reported to possess significant antioxidant property, their protective effect against lead acetate induced nephrotoxicity has been investigated in this study by estimating biochemical, oxidative stress and antioxidant markers, histological and immunohistochemistry of KIM 1 expression. ${ }^{4}$

The kidney is one of the most highly differentiated organs in the body that modulates a variety of physiologic processes especially the removal of drug metabolites. As per the Global Burden of Disease Study (2010), kidney diseases ranked $18^{\text {th }}$ in the list of
Submission Date: 01-02-2021; Revision Date: 28-07-2021; Accepted Date: 15-10-2021

DOI: 10.5530/ijper.55.4.211 Correspondence: Prof. J Vijayakumar, Department of Anatomy, Saveetha Medical College and Hospital, Saveetha Institute of Medical and Technical Sciences (Deemed to be University), Chennai- 602 105, Tamil Nadu, INDIA. Phone: 09840059142, Email-mevsig@gmail.com

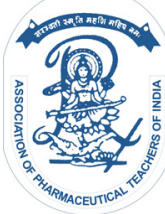

www.ijper.org 
causes of the total number of deaths worldwide that stood $27^{\text {th }}$ in $1990 .^{5}$ About $10 \%$ of the population worldwide is affected by kidney diseases and in several countries, its prevalence is increasing, mostly owing to the aging population and changing lifestyles, parallel to the growing prevalence of obesity. ${ }^{6}$ Oxidative stress in renal tissue occurs due to the production of reactive oxygen species (ROS) by activated inflammatory cells, such as macrophages and eosinophils. The superoxides production by nicotinamide adenine dinucleotide phosphate (NADPH) oxidase in phagocytes and endothelial cells is also the major cause of oxidative stress. ${ }^{7}$ The presence of naturally-occurring and chemically manufactured toxicants in the environment, individuals are exposed frequently over their lifetime to toxicants that can adversely affect the kidney. ${ }^{8}$ Lead Acetate (LA) has been found to negatively impact antioxidant activity by interfering with the metals that are essential for antioxidant enzyme activities. ${ }^{9}$ Prevention, early identification and treatment of the underlying cause are essential strategies to be followed for patients with kidney diseases.

\section{MATERIALS AND METHODS}

\section{Chemicals}

All chemicals used in the study were of analytical grade procured from SISCO Research Laboratories Private Limited and D. K. Enterprises, India. The reagents for antioxidants and oxidative markers were procured from Sigma Aldrich, USA.

\section{Procurement and preparation of the plant material}

C. paniculatus seeds were procured from M/s. Herbal Care and Cure Centre, Chennai and authenticated by Dr. V. Chelladurai, Pharmacognosist, St. Xavier's College, Tirunelveli. They were shade dried and coarsely powdered using mortar and pestle. About $500 \mathrm{~g}$ of this was soaked in $1 \mathrm{~L}$ of $90 \%$ ethanol in the aspirator bottle. After $72 \mathrm{~h}$, the solvent was filtered and distilled off. Final traces of the solvent were removed under vacuum to obtain the extract (EECP) for biological studies. Earlier reports revealed that the extract was safe up to a dose of $5000 \mathrm{mg} / \mathrm{kg}$ b.w. in rats. ${ }^{10}$

\section{Experimental animals}

The study was conducted after obtaining approval from the Institutional Animal Ethics Committee (No: SU/ CLAR/RD/002/2019) dated 09.08.2019. Thirty female Wistar rats $(180 \pm 20 \mathrm{~g})$ procured from Biogen Animal Facility, Bangalore. During acclimatization and experimental periods, the animals were housed in normal laboratory conditions $\left(25 \pm 2^{\circ} \mathrm{C}\right.$, relative humidity:
50-70\% and $12 \mathrm{~h}$ light-dark cycle) and fed with the standard pellet diet and free access to water.

\section{Experimental design}

The animals were divided into five groups $(n=6)$ as follows and the study was carried out for 28 days.

Group 1: Saline ( $2 \mathrm{~mL} / \mathrm{kg}$ b.w/day, p.o.)

Group 2: LA (30mg/kg b.w/day, p.o.)

Group 3: NAC (200 mg/kg b.w/day, p.o.) +

LA $(30 \mathrm{mg} / \mathrm{kg}$ b.w/day, p.o.)

Group 4: EECP (400mg/kg b.w/day, p.o.) +

LA $(30 \mathrm{mg} / \mathrm{kg}$ b.w/day, p.o.)

Group 5: EECP (800 mg/kg b.w/day, p.o.) +

LA $(30 \mathrm{mg} / \mathrm{kg}$ b.w/day, p.o.)

After the study period, on day 29 , the animals were anesthetized using 1\% isoflurane for blood collection and euthanized to harvest the kidneys which were stored at $80^{\circ} \mathrm{C}$ for further analysis.

\section{Estimation of serum urea and creatinine}

About $2 \mathrm{~mL}$ of blood was collected in heparinized Eppendorf tubes from the retro-orbital sinus by a capillary tube and centrifuged to separate serum for biochemical analysis. Renal biomarkers urea and creatinine were determined by standard methods. ${ }^{11,12}$

\section{Estimation of oxidative stress and antioxidant parameters}

The renal tissues were homogenized and analyzed for catalase, glutathione peroxidase, glutathione reductase, glutathione, glutathione S-transferase, superoxide dismutase activities besides estimating hydrogen peroxide, lipid peroxide, hydroxyl radical by established procedures. ${ }^{13-21}$ Estimation of Serum Kidney Injury Molecule 1 (KIM 1). The presence of KIM-1 in serum were detected using the KIM 1 ELISA kit according to the instructions in the manufacturer's manual. The samples along with coating buffer were mounted to 96-well plates and incubated overnight at $4{ }^{\circ} \mathrm{C}$. The remaining proteinbinding sites were then blocked by incubating samples for $1.5 \mathrm{~h}$ with blocking buffer containing 2\% fetal bovine serum at $37^{\circ} \mathrm{C}$. Primary mouse anti-rat KIM-1 monoclonal antibodies (dilution, 1:1,000) and goat anti-mouse IgG secondary antibodies (dilution, 1:2,000) were added to bind specifically with the target antigen. Following treatment with 3,3-diaminobenzidene (DAB) solution from the ELISA kit and stop buffer, the plates were read at $490 \mathrm{~nm}$ using a microplate reader.

\section{Histopathological Studies}

After the experimental period, the animals were euthanized; the kidneys were harvested and fixed in $10 \%$ 
formalin. The dehydration process was employed by immersing the tissues in a series of ethanolic solutions of increasing concentration to avoid excessive distortion of the tissue. The tissues were embedded in the paraffin embedding medium and the paraffin sections were cut at a thickness of $3-5 \mu \mathrm{m}$ with a rotatory microtome. The slides were stained with Hematoxylin and Eosin (H\&E) and observed under 100X and 400X magnifications with the compound microscope. The cortex and medullary regions of the kidney were examined for cytoarchitectural changes and photographs were done.

\section{Immunohistochemistry analysis of expression of KIM 1}

Immunohistochemistry staining against KIM 1 was performed. After antigen retrieval $(100 \times$ Citrate Buffer) for $20 \mathrm{~min}$ in a domestic pressure cooker and blocking non-specific binding sites with protein block, the sections were immunoreacted with primary antibodies against ALA-D (Thermo Fischer Scientific Company) overnight at $4^{\circ} \mathrm{C}$, respectively. KIM-1 antibody (R and D Systems, Minneapolis, USA) and AQP-1 rabbit polyclonal antibody (EMD Millipore, Temecula, USA) were applied overnight at $4^{\circ} \mathrm{C}$. The hematoxylin stain was used to counterstain the slides. Finally, the sections were incubated with DAB-hydrogen peroxide for $30 \mathrm{~min}$ and washed in water, counterstained and viewed under the light microscope. Five $200 \mathrm{X}$ microscopic views per slide were selected randomly and photographed using Image J Software.

\section{Statistical analysis}

The data obtained from the experiments were analyzed using One-way ANOVA with SIGMA PLOT 13 using SYSTAT software followed by Newman Keul's test for comparison between the groups. The values were expressed as mean \pm SEM and those with $P<0.001$ were considered statistically significant.

\section{RESULTS}

\section{Effects of EECP on serum urea and creatinine}

The effect of EECP on serum urea and creatinine are shown in Table 1 . The LA treated animals in group 2 showed a noticeable elevation in urea and creatinine when compared to the normal rats in group1. However, in EECP-treated groups, there was a remarkable decline in their levels as compared to standard-drug treated group 3 . The decrease was highly significant in the $800 \mathrm{mg}$ treated group.
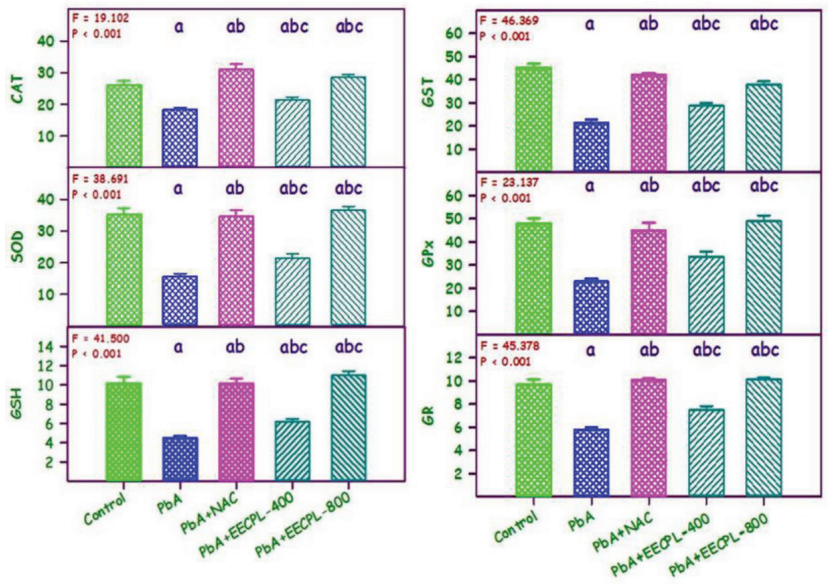

Figure 1: Effect of ethanolic extract of $C$. paniculatus seeds $400 \mathrm{mg} / \mathrm{kg}$ (EECP-400) and $800 \mathrm{mg} / \mathrm{kg}$ (EECP-800) compared with n-acetylcysteine (NAC $200 \mathrm{mg} / \mathrm{kg}$ ) in lead acetate toxicity (LA, $30 \mathrm{mg} / \mathrm{kg}$ ) on antioxidant markers. Data are expressed as mean + SE ( $n=6$ each). The ' $F$ ' and ' $P$ ' values are by one way ANOVA with Student Newman Keul's multiple comparison test. a: Significantly different from the control group, b: Significantly different from LA group, c: Significantly different from NAC group.

\section{Effects of EECP on oxidative stress markers and antioxidant enzymes}

The LA-induced nephrotoxic rats showed a significant increase in oxidative stress markers along with decreased levels of antioxidant enzymes in renal tissues as compared to normal animals. The increased levels of oxidative stress markers were found to be reverted to near normal status after the administration of EECP $(800 \mathrm{mg} / \mathrm{kg}$ b.w.). Co-administration of EECP also significantly increased antioxidant enzyme activities in comparison with group 3 rats (Figure 1 and Table 1) (Figure 2 and Table 2). The EECP was found to possess an antioxidant effect in a dose-dependent manner.

\section{Effects of EECP on serum KIM 1}

The level of the serumKIM-1 showed in Figure 3. There was a significant up-regulation of KIM-1in the LA group compared with control animals. Administration of NAC $(200 \mathrm{mg} / \mathrm{kg}$ b.w.), 400 and $800 \mathrm{mg} / \mathrm{kg}$ b.w. of EECP were significantly attenuated the up-regulated KIM 1. EECP $(800 \mathrm{mg} / \mathrm{kg}$ b.w) and NAC offered full protection when compared to control animals, whereas EEPC $(400 \mathrm{mg} / \mathrm{kg}$ b.w) offered partial protection when compared to control animals. It was found to be statistically significant $(P<0.001)$.

\section{Effect of EECP on the histology of kidney}

The histology of the renal tissues of control, NAC $(200 \mathrm{mg} / \mathrm{kg}$ b.w) and EECP $(800 \mathrm{mg} / \mathrm{kg}$ b.w) showed normal cytoarchitecture which compared with LA 
Table 1: Protective effect of Celastrus paniculatus seed extract on lead acetate induced changes in antioxidant markers. Value are mean \pm SEM $(n=6$ each).

\begin{tabular}{|c|c|c|c|c|c|c|}
\hline Group & CAT & GSH & SOD & \multicolumn{2}{|c|}{ GST } & GPx \\
\hline Control & $26.167 \pm 1.22$ & $10.167 \pm 0.65$ & $35.333 \pm 1.91$ & $45 \pm 2.08$ & $47.833 \pm 2.22$ & $9.655 \pm 0.45$ \\
\hline PbA & $18.333 \pm 0.61$ & $4.5 \pm 022$ & $15.667 \pm 0.88$ & $21.167 \pm 1.42$ & $22.833 \pm 1.32$ & $5.775 \pm 0.17$ \\
\hline NAC & $31 \pm 1.84$ & $10.167 \pm 0.47$ & $34.667 \pm 1.96$ & $42 \pm 0.81$ & $45 \pm 3.29$ \\
\hline EECPL-400 & $21.333 \pm 0.98$ & $6.167 \pm 0.30$ & $21.5 \pm 1.31$ & $28.833 \pm 1.01$ & $33.667 \pm 2.04$ & $7.475 \pm 0.35$ \\
\hline EECPL-800 & $28.5 \pm 0.88$ & $11 \pm 0.45$ & $36.5 \pm 1.29$ & $37.833 \pm 1.537$ & $49 \pm 2.30$ & $10.108 \pm 0.14$ \\
\hline
\end{tabular}

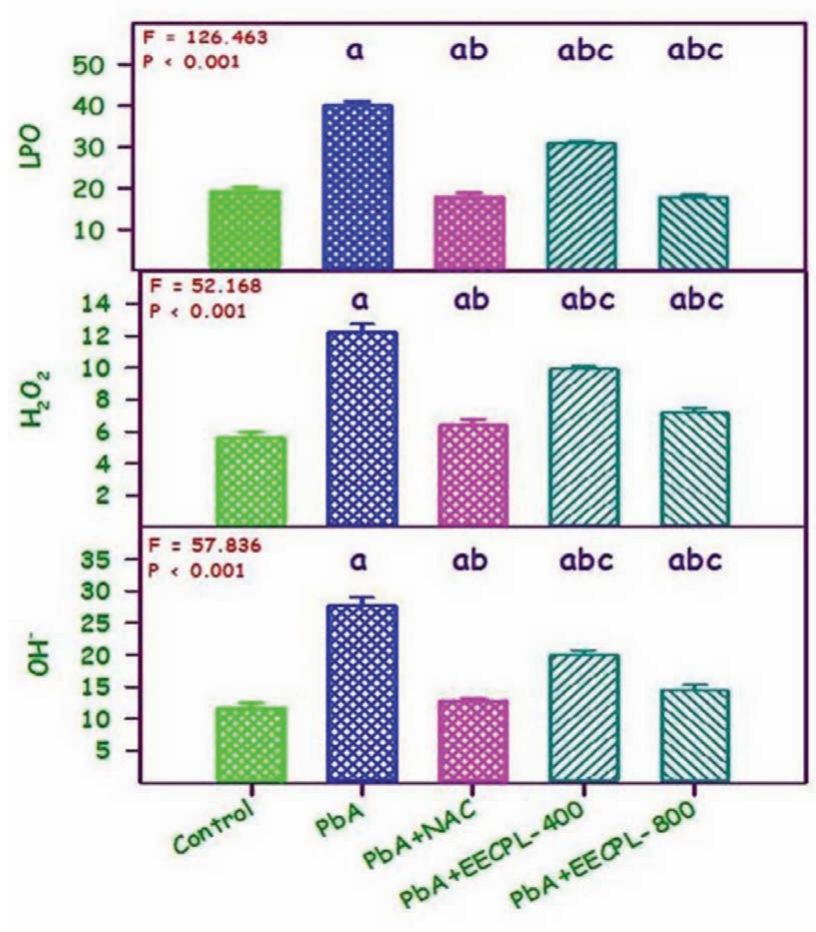

Figure 2: Effect of ethanolic extract of C. paniculatus seeds $400 \mathrm{mg} / \mathrm{kg}$ (EECPL-400) and $800 \mathrm{mg} / \mathrm{kg}$ (EECPL-800) compared with n-acetylcysteine (NAC $200 \mathrm{mg} / \mathrm{kg}$ ) in lead acetate toxicity $(\mathrm{PbA}, 30 \mathrm{mg} / \mathrm{kg})$ on oxidative stress markers. Data are expressed as mean + SE ( $n=6$ each). The 'F' and 'P' values are by one way ANOVA with Student Newman Keul's multiple comparison test. a: Significantly different from the control group, b: Significantly different from $\mathrm{PbA}$ group, c: Significantly different from NAC group.

Table 2: Protective effect of Celastrus paniculatus seed extract on lead acetate induced changes in oxidative markers. Value are mean $\pm \operatorname{SEM}(n=6$ each).

\begin{tabular}{|c|c|c|c|}
\hline Group & LPO & $\mathbf{H}_{2} \mathrm{O}_{2}$ & $-\mathrm{OH}$ \\
\hline Control & $19.167 \pm 1.04$ & $5.585 \pm 0.53$ & $11.667 \pm 0.80$ \\
\hline $\mathrm{PbA}$ & $40 \pm 1.06$ & $12.197 \pm 0.53$ & $27.667 \pm 1.33$ \\
\hline $\mathrm{NAC}$ & $17.833 \pm 1.04$ & $6.368 \pm 0.43$ & $12.833 \pm 0.40$ \\
\hline EECPL-400 & $30.833 \pm 0.54$ & $9.91 \pm 0.18$ & $20 \pm 0.77$ \\
\hline EECPL-800 & $17.833 \pm 0.53$ & $7.173 \pm 0.30$ & $14.5 \pm 0.76$ \\
\hline
\end{tabular}

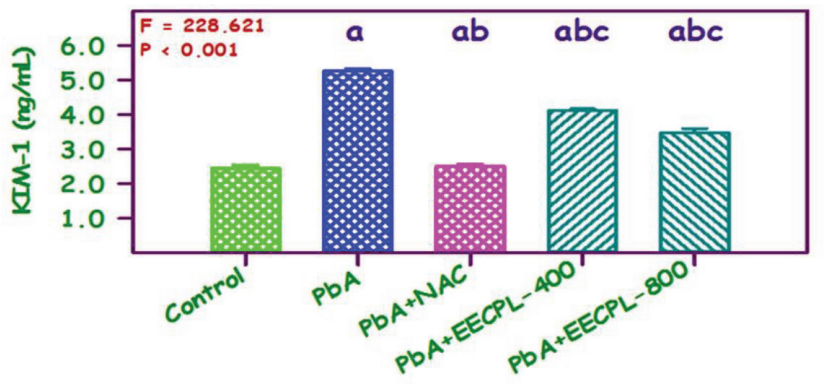

Figure 3: Effect of ethanolic extract of $C$. paniculatus seeds $400 \mathrm{mg} / \mathrm{kg}$ (EECPL-400) and $800 \mathrm{mg} / \mathrm{kg}$ (EECPL-800) compared with n-acetylcysteine (NAC $200 \mathrm{mg} / \mathrm{kg}$ ) in lead acetate toxicity ( $\mathrm{PbA}, 30 \mathrm{mg} / \mathrm{kg}$ ) on serum KIM 1markers. Data are expressed as mean + SE ( $n=6$ each). The ' $F$ ' and 'P' values are by one way ANOVA with Student Newman Keul's multiple comparison test. a: Significantly different from the control group, b: Significantly different from $\mathrm{PbA}$ group, c: Significantly different from NAC group.

$(30 \mathrm{mg} / \mathrm{kg}$ b.w) and EECP $(400 \mathrm{mg} / \mathrm{kg}$ b.w). The microanatomy of the kidney with normal glomeruli having well-structured bowman's capsule, distal and proximal convoluting tubules in the cortexand collecting duct in the medulla in control, NAC $(200 \mathrm{mg} / \mathrm{kg}$ b.w $)$ and EECP $(800 \mathrm{mg} / \mathrm{kg}$ b.w). In LA ( $30 \mathrm{mg} / \mathrm{kg}$ b.w) administered animals showed atrophy of glomeruli and dilatations were seen in Bowman's capsule, the renal tubules are also dilated with coagulative necrosis. Co-administration of LA and EECP $(400 \mathrm{mg} / \mathrm{kg}$ b.w) showed shrunken glomeruli, inflammation and degenerative changes in renal tubules and mild coagulation necrosis in renal tissue (Figure 4).

\section{Effect of EECP on the expression of KIM 1 using immunohistochemistry}

The immunohistochemistry of the expression of KIM-1 in the renal tissues was shown in Figure 5. The renal tissue of the LA $(30 \mathrm{mg} / \mathrm{kg}$ b.w) administered group showed immunoprecipitation of KIM-1 in the glomeruli and renal tubules, more commonly in the proximal tubules. Moreover, in EECP $(400 \mathrm{mg} / \mathrm{kg}$ b.w) administered animals showed minimal immunoprecipitation when 


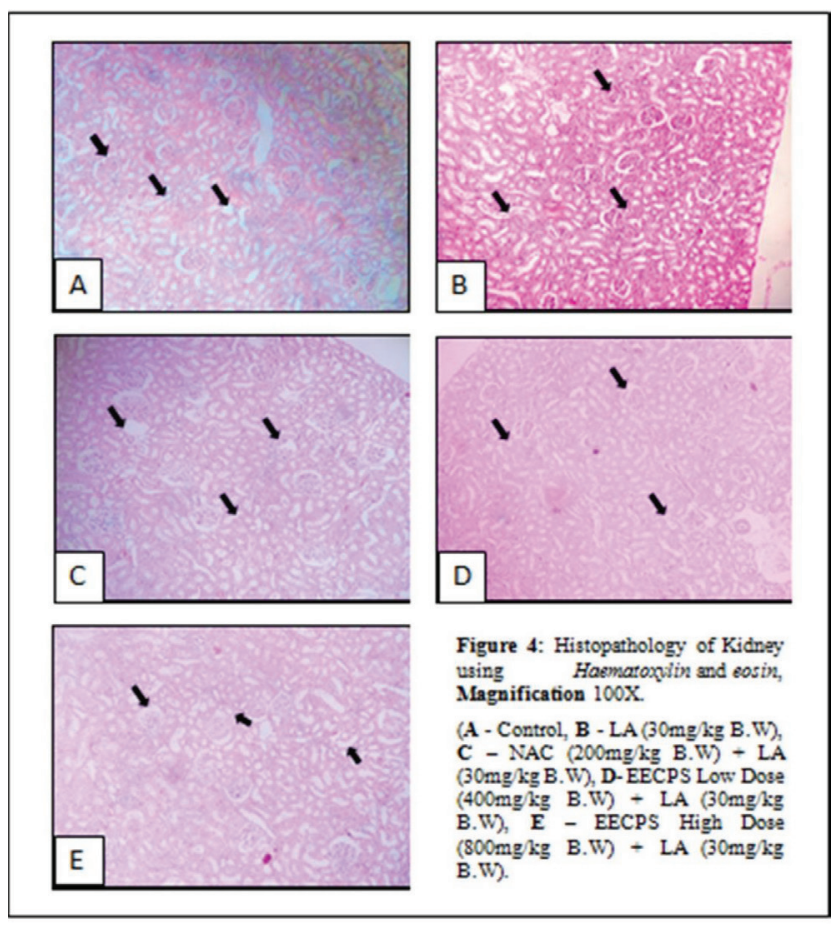

Figure 4: Histopathology of Kidney using Haematoxylin and eosin, Magnification 100X.

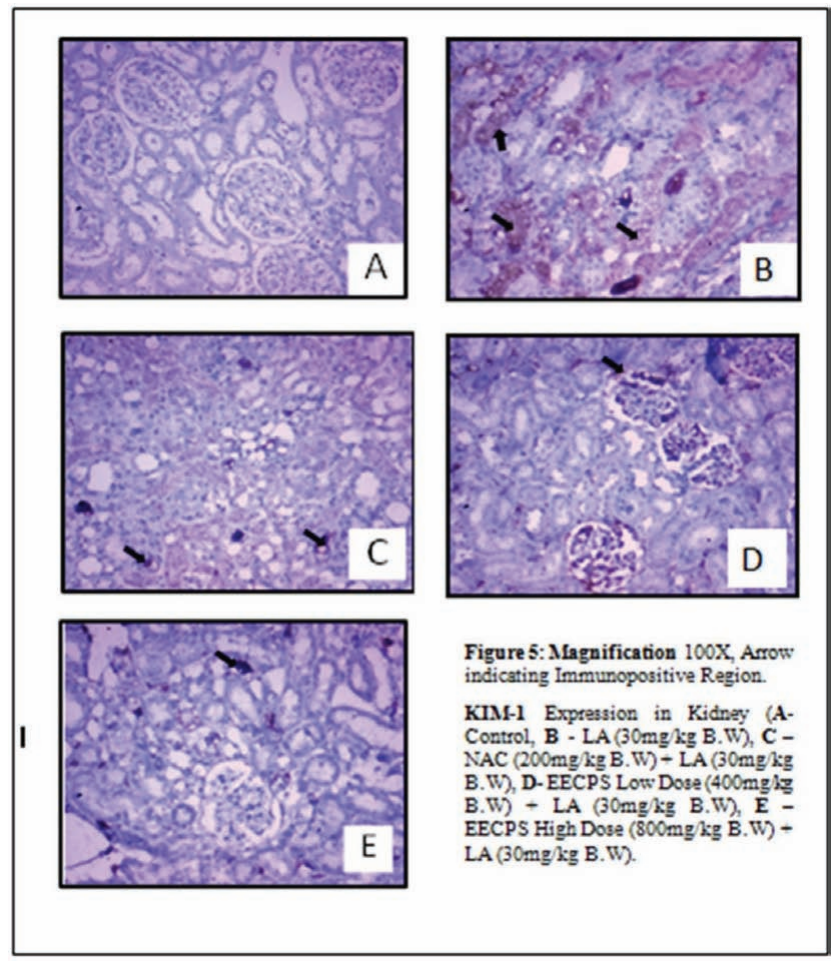

Figure 5: Immunohistochemistry KIM 1 Expression, Magnification 100X, Arrow indicating Immunopositive Region. KIM-1 Expression in Kidney (A- Control, B - LA (30 mg/kg B.W), C -NAC (200mg/kg B.W) + LA (30 mg/kg B.W), D- EECPS Low Dose $(400 \mathrm{mg} / \mathrm{kg} \mathrm{B.W})+$ LA (30mg/kg B.W), E - EECPS High Dose $(800 \mathrm{mg} / \mathrm{kg} \mathrm{B.W})+$ LA (30 mg/kg B.W). compared to LA administrated group. No immunoreactivity of KIM-1 in the NAC $(200 \mathrm{mg} / \mathrm{kg}$ b.w) and EECP $(800 \mathrm{mg} / \mathrm{kg}$ b.w) groups which is similar to the control group that also showed no immunoreactivity of KIM 1.

\section{DISCUSSION}

Heavy metal toxicity is a serious issue that affects living organisms and causes morbidity and mortality in humans. It is also reported to be of environmental concern in many parts of the world. Lead, a ubiquitous heavy metal and a known toxicant also produces adverse effects on the brain via increased production of reactive oxygen species (ROS) and causes oxidative stress. ${ }^{22}$ This, in turn, results in oxidative stress at the cellular level causing a reduction in the sarcolemmal calcium pump and $\mathrm{Na}^{+} \mathrm{K}^{+}$ATPase intracellular $\mathrm{Ca}^{2+}$ overload. Lead can substitute for calcium ions $\left(\mathrm{Ca}^{2+}\right)$ and picomolar concentrations of $\mathrm{Pb}^{2+}$ can replace micromolar concentrations of $\mathrm{Ca}^{2+}$ in a protein kinase $\mathrm{C}$ (PKC) enzyme assay, a calcium-dependent process. ${ }^{23}$ The literature on lead toxicity also mentions its adverse effect on kidney function due to increased oxidative stress in renal tissues. Various remedies were suggested to tackle this malady in which the use of plants and plant-derived metabolites has been found to play a key role. The utility of plants as a remedial measure is a subtle approach because of their easy availability and accessibility. ${ }^{24}$ In this investigation, the seed extract of $C$. paniculatus (EECP) has been taken up to find out its free radical scavenging potential in lead acetate induced nephrotoxicity in the rat model. The antioxidant activity of C. Paniculatus seeds in rats intoxicated with aluminum was already evaluated and its protective effect on the levels of antioxidants CAT, GSH and SOD were investigated. The results showed that aluminum significantly decreased the above parameters on treatment with $C$. paniculatus seeds at the dose of $200 \mathrm{mg} / \mathrm{kg} \mathrm{b}$. w. significantly increased..$^{25}$ The antioxidants present in the plant prevent the ROS-oxidation of vital molecules in the cell and scavenge free radicals thereby reducing the harmful effects. ${ }^{26,27}$

A similar study on $C$. paniculatus seed extract showed scavenging activity of the stable 1,1-diphenyl-2- picrylhydrazyl (DPPH) free radical. ${ }^{28}$ The aqueous extract of C. paniculatus seeds at the dose of $200 \mathrm{mg} / \mathrm{kg}$ b.w for 14 days showed significant improvement in learning and memory in animals. The extract also stimulated a significant decrease in the level of malondialdehyde with a concomitant increase in the levels of GST and CAT. The effects of ethanolic and methanolic extracts 
of C. paniculatus seed oil against $\mathrm{H}_{2} \mathrm{O}_{2}$ and glutamateinduced superoxide scavenging were determined using neuronal cell culture. The results showed that $C$. paniculatus seed oil protected cells against $\mathrm{H}_{2} \mathrm{O}_{2}$ induced oxidative stress by their ability to improve the levels of antioxidant enzymes. $^{29}$

In an in-vitro study, the antioxidant defense of ethanolic extract $C$. paniculatus seeds on murine $\mathrm{C}_{2} \mathrm{C}_{12}$ myoblasts cells was experimentally proved. The protective effect of C. paniculatus seed extract-treated against t-BHPtreatment was confirmed by antioxidant markers of $\mathrm{C}_{2} \mathrm{C}_{12}$ muscle cells. The levels of antioxidant markers were reduced in t-BHP treated cells, which were significantly restored in C. paniculatus seed extract-treated cells. ${ }^{30}$

The present study demonstrated that LA ingestion led to a significant increase in $\mathrm{H}_{2} \mathrm{O}_{2}, \mathrm{OH}^{-}$and LPO levels in renal tissues. Administration of EECP led to a marked decrease in the elevated levels of these parameters in rat tissues. This is attributed to the antioxidant properties of $C$. paniculatus seeds that protect rat's kidneys from oxidative damage and repair the antioxidant system. The decreased levels of antioxidant enzymes(CAT, GPx, SOD, GR, GST and GSH) was improved near to normal values after EECP administration especially at $800 \mathrm{mg} / \mathrm{kg}$ b.w. dose when compared to the standard drug-treated animals (Figure 1 and 2).

The Food and Drug Administration and European Medicines Agency recognized KIM-1 to be a sensitive marker for finding renal damage. KIM-1 $(25 \mathrm{Kda})$ is a transmembrane glycoprotein with an immunoglobulin domain and mucin. ${ }^{31}$ Serum KIM-1 is a sensitive marker of kidney damage in the general population, particularly in middle-aged adults. Serum KIM 1 is a potential predictive biomarker when compared with urine KIM1. ${ }^{32,33}$ Hence, in this study, serum KIM-1 was used as the parameter to assess the renal damage.

KIM 1 is a novel marker that is used to analyze the damage in addition to urea and creatinine, which are standard markers. The gentamicin induced nephrotoxicity in rats up-regulated the KIM 1 along with standard renal markers and antioxidant enzymes ameliorated by plant extract. ${ }^{34}$ A similar result was reported in cadmium-induced nephrotoxicity in male mice. ${ }^{35}$ In this study, there was significant up-regulation of KIM 1 in LA administrated animals which were attenuated by EECP $(800 \mathrm{mg} / \mathrm{kg}$ b.w) (Figure 3).

The histopathological finding of this study showed that LA (30 mg/kg b.w) produces significant nephrotoxicity of the kidneys such as shrunken and atrophy of glomeruli, inflammation and degenerative changes in renal tubules and mild to moderate coagulation necrosis in renal tissue (Figure 4). These findings in LA administrated animals correlate with previous studies. ${ }^{36,37}$

Apparent renal markers such as KIM-1, NGAL, clusterin, vimentin, uromodulin, nephrin and netrin are investigated using immunohistochemistry. The early detection of renal damage is vital to protect it from progressive and severe complications. ${ }^{38}$ The animals administrated with LA produced a significant expression of KIM-1 in the renal cortex specifically the apical part of renal tubules showed more expression of KIM-1 indicating damage in the kidney which was similar to the earlier findings. ${ }^{39}$ Co-administration of LA and standard drug NAC (200 mg/kg b.w) showed no expression of KIM 1, similar to the previous report of cisplatin-induced nephrotoxicity. ${ }^{40}$ EECP $(800 \mathrm{mg} / \mathrm{kg} \quad$ b.w $)$ showed expression of KIM 1, similar to NAC (200 mg/ $\mathrm{kg} \mathrm{b.w)}$ (Figure 5), Whereas EECP (400 mg/kg b.w) showed minimal expression of KIM-1 in the immunohistochemistry of the renal tissue.

In this study, co-administration of Celastrus paniculatus seed $(800 \mathrm{mg} / \mathrm{kg}$ b.w) reverted the serum parameters and microanatomy of renal tissue from LA induced toxicity. The flavonoids in Celastrus paniculatus seed modulate the adverse effects of lead acetate and redeem the kidney damage. The results demonstrate that EECP has effectively ceased the LA induced oxidative stress and renal damage by providing free radical scavenging property and by assisting in the synthesis of glutathione. Thus, EECP exhibits nephroprotection by above said two mechanisms which required further studies to explore which might aid in greater characterize the mechanisms.

\section{CONCLUSION}

The results obtained in this study suggest that C.paniculatus seeds possess significant nephroprotective properties which might be due to secondary metabolites present in them. Identification and isolation of these bioactive compounds will give scope for future research in finding useful drugs to overcome lead toxicity.

\section{ACKNOWLEDGEMENT}

The authors are thankful to SIMATS (Department of Research and Development), Chennai, India, which gave the facility to carry out extract preparation and animal laboratory work. The authors are thankful to Dr Ethirajan Sukumar, former Research Dean, SIMATS and Dr Selvaraj J, Associate Professor, Department of Biochemistry, SDCH for his valuable contribution in preparation of extract and also to Mr Madhan Kumar and $\mathrm{Mr}$ Praveen Kumar for their assistance during 
extract preparation. The authors are thankful to Mr Chelladurai for his support in the procurement of plant material. The authors also wish to thank $\mathrm{Mr}$ Arun Kumar, REFSYN Biosciences Pvt Ltd. Puducherry, for his assistance in carrying out the laboratory woks.

\section{CONFLICT OF INTEREST}

The authors don't have any conflicting interests.

\section{ABBREVIATIONS}

EECP: Ethanolic extract of the Celastrus paniculatus; CP: Celastrus paniculatus; LA: Lead acetate; CAT: Catalase; GPx: Glutathione peroxidase; SOD: Superoxide dismutase; $\mathbf{H}_{2} \mathbf{O}_{2}$ : Hydrogen peroxide; GR: Reduced glutathione; GST: Glutathione S-transferase; GSH:Glutathione; $\mathbf{O H}^{-}$: Hydroxyl Radicals; LPO: Lipid peroxidation; KIM 1: Kidney injury molecule 1; NGAL: Neutrophil gelatinase-associated lipocalin; ROS: Reactive oxygen species; NADPH: Nicotinamide adenine dinucleotide phosphate; DPPH: 1,1-diphenyl-2picrylhydrazyl; $\mathrm{Ca}^{2+}$ : Calcium ion; $\mathbf{P b}^{2+}$ : Lead ion; PKC: Protein kinase C; ANOVA: Analysis of variance; SEM: Standard error of mean; mL: Milli Liter; ${ }^{\circ} \mathbf{C}$ : Degree Centigrade; mg: Miligram; kg b.w: Kilogram body weight.

\section{REFERENCES}

1. Bhanumathy M, Harish MS, Shivaprasad HN, Sushma G. Nootropic activity of Celastrus paniculatus seed. Pharm Biol. 2010;48(3):324-7. doi: 10.3109/13880200903127391, PMID 20645820.

2. Kumaraswamy $\mathrm{ON}$, Manjunath BL. Chemical examination of the fixed oil from the seeds of Celastrus paniculatus Willd. Journal of Indian Chemical Society. 1936; 13: 353-357.

3. Parimala S, Shashidhar GH, Chigurupati S, Jyothi V, Suthakaran R. Antiinflammatory activity of Celastrus paniculatus seeds. Int J PharmTech Res. 2009; 1;4304:974

4. Zohera FT, Habib MR, Imam MZ, Mazumder MEH, Rana MS. Comparative Antioxidant Potential of Different Extracts of $<i>$ Celastrus paniculatus $</ i>$ Willd. Seed SJ Pharm Sci. 2010;3(1):68-74. doi: 10.3329/sjps.v3i1.6802.

5. Jha V, Garcia-Garcia G, Iseki K, Li Z, Naicker S, Plattner B, Saran R, Wang AY, Yang CW. Chronic kidney disease: global dimension and perspectives. Lancet. 2013;382(9888):260-72. doi: 10.1016/S0140-6736(13)60687-X, PMID 23727169.

6. Câmara NO, Iseki K, Kramer H, Liu ZH, Sharma K. Kidney disease and obesity: epidemiology, mechanisms and treatment. Nat Rev Nephrol. 2017;13(3):181-90. doi: 10.1038/nrneph.2016.191, PMID 28090083

7. Winterbourn CC, Kettle AJ, Hampton MB. Reactive oxygen species and neutrophil function. Annu Rev Biochem. 2016;85:765-92. doi: 10.1146/ annurev-biochem-060815-014442, PMID 27050287.

8. Orr SE, Bridges CC. Chronic kidney disease and exposure to nephrotoxic metals. Int J Mol Sci. 2017;18(5):1039. doi: 10.3390/ijms18051039, PMID 28498320.

9. Conterato GM, Augusti PR, Somacal S, Einsfeld L, Sobieski R, Torres JR, Emanuelli T. Effect of lead acetate on cytosolic thioredoxin reductase activity and oxidative stress parameters in rat kidneys. Basic Clin Pharmacol Toxicol. 2007;101(2):96-100. doi: 10.1111/j.1742-7843.2007.00084.x, PMID 17651309.
10. Kumar MHV, Gupta YK. Antioxidant property of Celastrus paniculatus Willd.: A possible mechanism in enhancing cognition. Phytomedicine. 2002;9(4):302-11. doi: 10.1078/0944-7113-00136, PMID 12120811

11. Geyer JW, Dabich D. Rapid method for determination of arginase activity in tissue homogenates. Anal Biochem. 1971;39(2):412-7. doi: 10.1016/00032697(71)90431-3, PMID 5555470.

12. Slot C. Plasma creatinine determination. A new and specific Jaffe reaction method. Scand J Clin Lab Investig. 1965;17(4):381-7. doi: 10.3109/00365516509077065, PMID 5838275.

13. Sinha AK. Colorimetric assay of catalase. Anal Biochem. 1972;47(2):389-94. doi: 10.1016/0003-2697(72)90132-7, PMID 4556490.

14. Rotruck JT, Pope AL, Ganther HE, Swanson AB, Hafeman DG, Hoekstra WG Selenium: biochemical role as a component of glutathione peroxidase. Science. 1973;179(4073):588-90. doi: 10.1126/science.179.4073.588, PMID 4686466.

15. Racker E. GLUTATHIONE REDUCTASE FROM BAKERS' YEAST AND BEEF LIVER. J Biol Chem. 1955;217(2):855-65. doi: 10.1016/S00219258(18)65950-2.

16. Moron MS, Depierre JW, Mannervik B. Levels of glutathione, glutathione reductase and glutathione $S$-transferase activities in rat lung and liver. Biochim Biophys Acta. 1979;582(1):67-78. doi: 10.1016/0304-4165(79)90289-7, PMID 760819.

17. Habig WH, Pabst MJ, Jakoby WB. Glutathione S-transferases. The first enzymatic step in mercapturic acid formation. J Biol Chem. 1974;249(22):7130-9. PMID 4436300.

18. Misra HP, Fridovich I. The role of superoxide anion in the autoxidation of epinephrine and a simple assay for superoxide dismutase. J Biol Chem. 1972;247(10):3170-5. doi: 10.1016/S0021-9258(19)45228-9, PMID 4623845.

19. Pick E, Keisari Y. Superoxide anion and hydrogen peroxide production by chemically elicited peritoneal macrophages--induction by multiple nonphagocytic stimuli. Cell Immunol. 1981;59(2):301-18. doi: 10.1016/00088749(81)90411-1, PMID 6269759.

20. Ohkawa $\mathrm{H}$, Ohishi $\mathrm{N}$, Yagi K. Assay for lipid peroxides in animal tissues by thiobarbituric acid reaction. Analytical Biochemistry. 1979;95(2):351-8. doi: 10.1016/0003-2697(79)90738-3.

21. Halliwell B. Gutteridge. J Free Radic Biol Med. 1987:4thedn.

22. Kumar KH, Venuprasad MP, Jayashree GV, Rachitha P, Krupashree K, Pal A, Khanum F. Celastrus paniculatus Willd. mitigates t-BHP induced oxidative and apoptotic damage in $\mathrm{C} 2 \mathrm{C} 12$ murine muscle cells. Cytotechnology. 2015;67(6):955-67. doi: 10.1007/s10616-014-9733-0, PMID 25118832.

23. Sanders T, Liu Y, Buchner V, Tchounwou PB. Neurotoxic effects and biomarkers of lead exposure: a review. Rev Environ Health. 2009;24(1):15-45. doi: 10.1515/reveh.2009.24.1.15, PMID 19476290.

24. Francis YM, Vijayakumar J, Raghunath G, Vijayalakshmi S, Sivanesan S, Vijayaraghavan R, Sukumar E. Protective effect of Carica papaya leaf extract against mercuric chloride-induced nephrotoxicity in Wistar rats. Phcog Mag. 2020;16(70):S379-84. doi: 10.4103/pm.pm_11_20.

25. Sumathi T, Shobana C, Mahalakshmi V, Surekha R, Subathra M, Vishali A, et al. Oxidative stress in brains of male rats intoxicated with aluminium andneuromodulating effect of Celastrus paniculatus alcoholic seed extract. Asian J Pharm Clin Res. 2013;6:80-90.

26. Adibmoradi M, Morovvati H Protective Effects of Wheat Sprout on Testicular Toxicity in Male Rats Exposed to Lead. Reprod Syst Sex Disord;04(4). doi: 10.4172/2161-038X.1000156.

27. Agarwal R, Goel SK, Behari JR. Detoxification and antioxidant effects of curcumin in rats experimentally exposed to mercury. J Appl Toxicol. 2010;30(5):457-68. doi: 10.1002/jat.1517, PMID 20229497.

28. Hassanien M, Kinni SG, Mörsel JT. Bioactive lipids, fatty acids and radical scavenging activity of Indian Celastrus paniculatus oil. J Appl Bot Food Qual. 2010;83:157-62.

29. Godkar PB, Gordon RK, Ravindran A, Doctor BP. Celastrus paniculatus seed oil and organic extracts attenuate hydrogen peroxide- and glutamate-induced injury in embryonic rat forebrain neuronal cells. Phytomedicine. 2006;13(1-2): 29-36. doi: 10.1016/j.phymed.2003.11.011, PMID 16360930.

30. Butt UJ, Shah SAA, Ahmed T, Zahid S. Protective effects of Nigella sativa L. seed extract on lead induced neurotoxicity during development and early life in mouse models. Toxicol Res (Camb). 2018;7(1):32-40. doi: 10.1039/ c7tx00201g, PMID 30090560. 
31. FDA. News. FDA, European Medicine Agency to consider additional test results when assessing new drug safety collaborative effort by FDA and EMEA expected to yield additional safety data. FDA News. 2008; Jun 12.

32. Schulz CA, Engström G, Nilsson J, Almgren P, Petkovic M, Christensson A, Nilsson PM, Melander O, Orho-Melander M. Plasma kidney injury molecule-1 (p-KIM-1) levels and deterioration of kidney function over 16 years. Nephrol Dial Transplant. 2020 Feb 1;35(2):265-73. doi: 10.1093/ndt/gfy382, PMID 30629206.

33. Khan FA, Fatima SS, Khan GM, Shahid S. Evaluation of kidney injury molecule-1 as a disease progression biomarker in diabetic nephropathy. Pak J Med Sci. 2019;35(4):992-6. doi: 10.12669/pjms.35.4.154, PMID 31372130.

34. Gheith I, El-Mahmoudy A. Novel and classical renal biomarkers as evidence for the nephroprotective effect of Carica papaya leaf extract. Biosci Rep. 2018 Sep 20;38(5). doi: 10.1042/BSR20181187, PMID 30206132.

35. Almeer RS, AlBasher GI, Alarifi S, Alkahtani S, Ali D, Abdel Moneim AE Royal jelly attenuates cadmium-induced nephrotoxicity in male mice. Sci Rep. 2019;9(1):5825. doi: 10.1038/s41598-019-42368-7. PMID 30967588.

36. Amjad Z, Yasmin T, Ashraf I, Perveen K, Mirza T, Shoro AA. Lead-induced morphometric changes in the kidneys of albino rats ameliorated by ginkgo biloba extract (EGb 761). J Pak Med Assoc. 2017 Jan;67(1):58-65. PMID 28065956.

37. Dua TK, Dewanjee S, Khanra R, Joardar S, Barma S, Das S, Zia-Ul-Haq M, De Feo V. Cytoprotective and antioxidant effects of an edible herb, Enhydra fluctuans Lour. (Asteraceae), against experimentally induced lead acetate intoxication. PLOS ONE. 2016 Feb 9;11(2):e0148757. doi: 10.1371/journal. pone.0148757, PMID 26859407.

38. Dieterle F, Sistare F, Goodsaid F, Papaluca M, Ozer JS, Webb CP, Baer W, Senagore A, Schipper MJ, Vonderscher J, Sultana S, Gerhold DL, Phillips JA, Maurer G, Carl K, Laurie D, Harpur E, Sonee M, Ennulat D, Holder D, Andrews-Cleavenger D, Gu YZ, Thompson KL, Goering PL, Vidal JM, Abadie E, Maciulaitis R, Jacobson-Kram D, Defelice AF, Hausner EA, Blank M, Thompson A, Harlow P, Throckmorton D, Xiao S, Xu N, Taylor W, Vamvakas S, Flamion B, Lima BS, Kasper P, Pasanen M, Prasad K, Troth S, Bounous D, Robinson-Gravatt D, Betton G, Davis MA, Akunda J, McDuffie JE, Suter L, Obert L, Guffroy M, Pinches M, Jayadev S, Blomme EA, Beushausen SA, Barlow VG, Collins N, Waring J, Honor D, Snook S, Lee J, Rossi P, Walker E, Mattes W. Renal biomarker qualification submission: a dialog between the FDA-EMEA and Predictive Safety Testing Consortium. Nat Biotechnol. 2010;28(5):455-62. doi: 10.1038/nbt.1625, PMID 20458315.

39. Vaidya VS, Ozer JS, Dieterle F, Collings FB, Ramirez V, Troth S, Muniappa N, Thudium D, Gerhold D, Holder DJ, Bobadilla NA, Marrer E, Perentes E, Cordier A, Vonderscher J, Maurer G, Goering PL, Sistare FD, Bonventre JV. Kidney injury molecule-1 outperforms traditional biomarkers of kidney injury in preclinical biomarker qualification studies. Nat Biotechnol. 2010 May;28(5):478-85. doi: 10.1038/nbt.1623, PMID 20458318.

40. Huang E, Sethi S, Peng A, Najjar R, Mirocha J, Haas M, Vo A, Jordan SC. Early clinical experience using donor-derived cell-free DNA to detect rejection in kidney transplant recipients. Am J Transplant. 2019 Jun;19(6):1663-70. doi: 10.1111/ajt.15289, PMID 30725531.

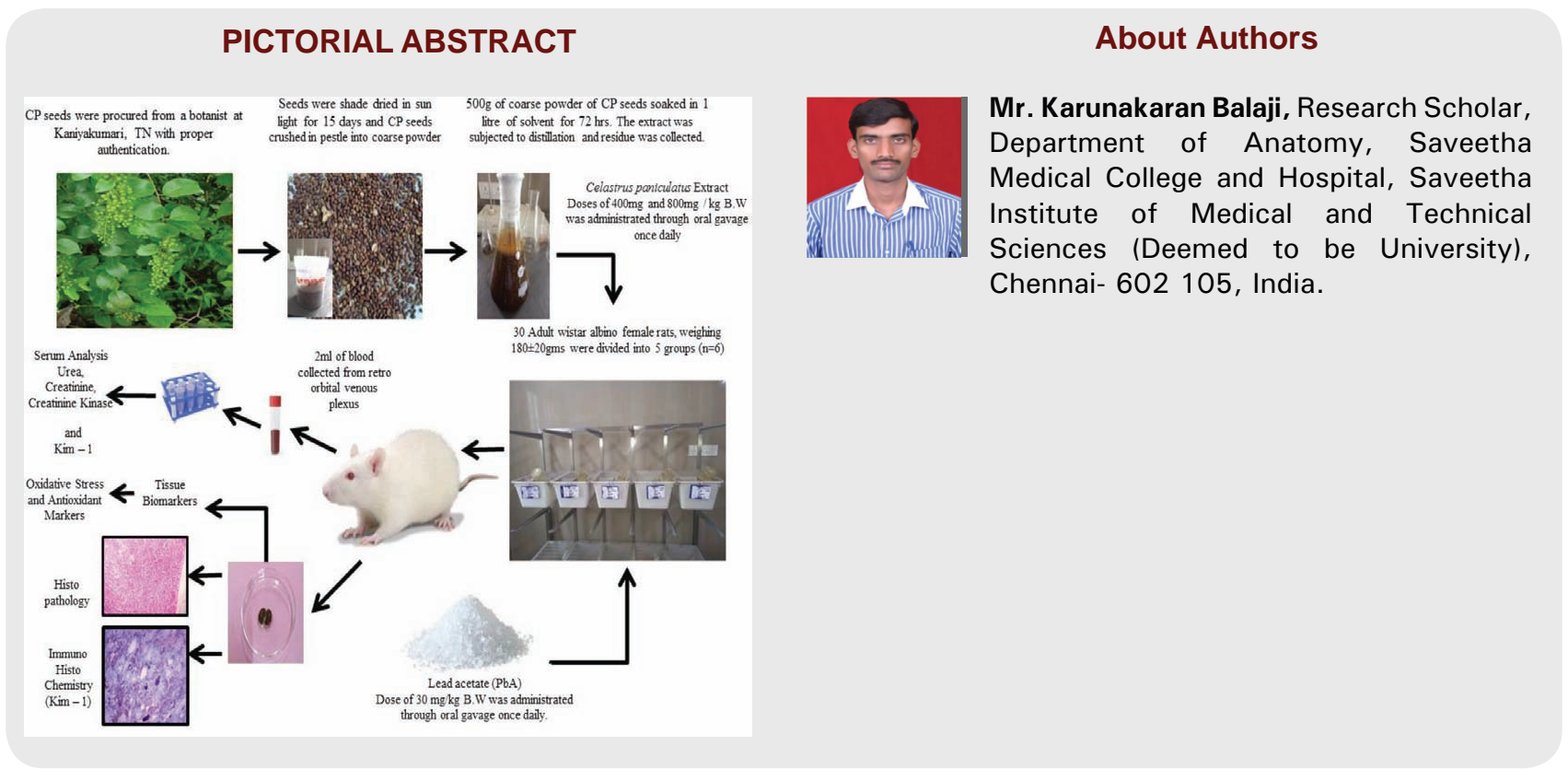

Cite this article: Balaji K, Vijayakumar J, Senthilkumar S, Vijayaraghavan R, Naveenkumar V. Protective Effect of Celastrus paniculatus Seed Extract against Lead Acetate Induced Nephrotoxicity in Wistar Rats. Indian $\mathrm{J}$ of Pharmaceutical Education and Research. 2021;55(4):1107-14. 